\title{
Pengaruh Model Pembelajaran Discovery Learning dengan Pendekatan Kontruktivisme terhadap Peningkatan Hasil Belajar Matematika Siswa
}

\author{
Tahir $^{1 *}$, Marniati $^{2}$ \\ 1,2 Universitas Sembilanbelas November Kolaka \\ *tahir.anwar.ta89@gmail.com
}

\begin{abstract}
ABSTRAK
Tujuan dari penelitian ini adalah untuk mengetahui perbedaan peningkatan hasil belajar matematika siswaantara siswa yang belajar menggunakan model pembelajaran discovery learning dengan pendekatan kontruktivisme dengan siswa yang belajar menggunakan model pembelajaran konvensional. Penelitian ini merupakan penelitian eksperimen yang bertujuan untuk mencari pengaruh perlakuan tertentu terhadap yang lain dalam kondisi yang terkontrol. Hasil penelitian diuji menggunakan uji hipotesis untuk mengetahui adanya perbedaan hasil belajar siswa antara siswa yang belajar menggunakan model pembelajaran discovery learning dengan pendekatan kontruktivisme dengan siswa yang belajar menggunakan model pembelajaran konvensional. Selain itu juga digunakan analisis statistik deskriptif untuk melihat perubahan sebelum dan sesudah perlakuan. Dari hasil penelitian menggunakan uji hipotesis dan analisis statistik deskriptif menunjukkan bahwa terdapat perbedaan peningkatan hasil belajar siswa yang belajar menggunakan model pembelajaran discovery learning dengan pendekatan kontruktivisme dengan siswa yang diajar dengan menggunakan model pembelajaran konvensional. Model pembelajaran discovery learning dengan pendekatan kontruktivisme dapat meningkatkan kemampuan belajar siswa sehingga terdapat perbedaan yang cukup signifikan antara kelompok siswa yang belajar menggunakan model pembelajaran discovery learning dengan pendekatan kontruktivisme dan kelompok siswa yang belajar dengan pembelajaran konvensional.
\end{abstract}

Kata kunci: discovery learning, kontruktivisme.

\begin{abstract}
The purpose of this study is to determine the differences in the improvement of students' mathematics learning outcomes between students who learn to use discovery learning models with constructivism approaches with students who learn to use conventional learning models. This research is an experimental research that aims to find the effect of certain treatments on others under controlled conditions. The results of the study were tested using a hypothesis test to find out the differences in student learning outcomes between students learning to use discovery learning models with constructivism approaches to students who learn to use conventional learning models. It also used descriptive statistical analysis to see changes before and after treatment. From the results of the study using hypothesis testing and descriptive statistical analysis shows that there are differences in the improvement of student learning outcomes that learn to use discovery learning models with constructivism approach to students who are taught using conventional learning models. Discovery learning model with constructivism approach can improve students' learning abilities so that there are significant differences between groups of students who learn to use discovery learning models with constructivist approaches and groups of students who study with conventional learning.
\end{abstract}

Keywords: discovery learning, constructivism. 


\section{PENDAHULUAN}

Pendidikan memiliki pengaruh yang besar terhadap perkembangan dan kemajuan bangsa. Melalui pendidikan suatu kemampuan dapat digali, dibiasakan, diarahkan, dan dikembangkan. Sehingga diperoleh suatu sumber daya yang dapat dimanfaatkan oleh masyarakat, bangsa, dan Negara. Matematika sebagai salah satu ilmu dasar merupakan mata pelajaran wajib pada semua jenjang pendidikan baik sekolah dasar, menengah maupun perguruan tinggi. Tujuan pembelajaran matematika di semua jenjang pendidikan persekolahan digolongkan atau diklarifikasikan menjadi tujuan yang bersifat formal dan tujuan yang bersifat material. Adapun tujuan yang bersifat formal lebih menekankan kepada menata penalaran dan membentuk kepribadian. Sedangkan tujuan yang bersifat material lebih menekankan kepada kemampuan menerapkan matematika dan keterampilan matematika.

Hal yang sangat perlu diperhatikan bahwa selama ini dalam praktek pembelajaran di kelas, guru lebih menekankan kepada tujuan yang bersifat material, antaralain karena tuntutan lingkungan yang sangat dipengaruhi oleh sistem evaluasi regional ataupun nasional. Ini mengakibatkan banyak orang menganggap bahwa tujuan pendidikan matematika hanyalah didomain kognitif saja. Sedangkan tujuan yang bersifat formal dianggap akan dicapai dengan sendirinya melalui perubahan yang diarahkan ke hal yang lebih baik misalnya setelah mengalami pembelajaran. Berkaitan dengan itu, berbagai lembaga khusus di bidang pendidikan telah melakukan berbagai penelitian untuk memahami inovasi pembelajaran yang dapat menjawab sekaligus meningkatkan kualitas pendidikan matematika. Berdasarkan penelitianpenelitian tersebut, dihasilkan berbagai pendekatan, metode dan model-model pembelajaran, yang diharapkan dapat diimplementasikan dalam pembelajaran matematika.

Pada umumnya kondisi belajar mengajar yang diciptakan dan disediakan oleh guru hingga saat ini untuk keperluan pembelajaran matematika masih menggunakan pembelajaran konvensional, dan cara mengajar guru masih kurang bisa dimengerti siswa sehingga hasil belajar siswa masih rendah. Demikian pula yang terjadi di SMP Negeri 2 Loea, dari hasil observasi dan wawancara yang dilakukan kemampuan belajar siswa masih kurang, seperti pada Gambar 1.

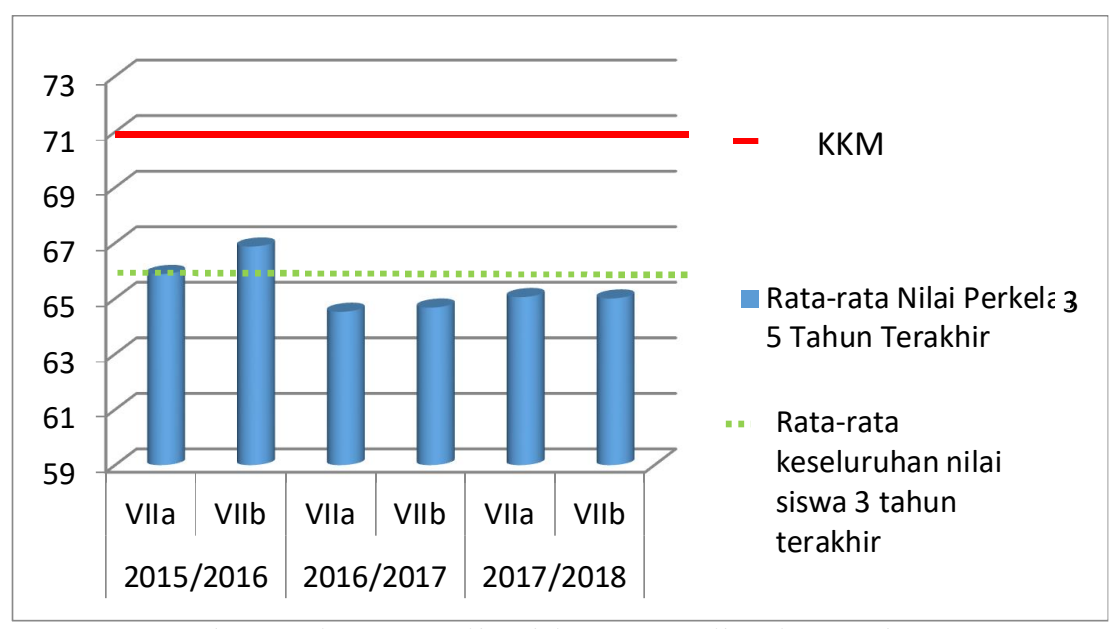

Gambar 1. Diagram Hasil Belajar Matematika Siswa Kelas VII SMP Negeri 2 Loea Tiga Tahun Terakhir 
Berdasarkan Gambar 1 tampak bahwa hasil yang diperoleh siswa selama lima tahun terakhir yang dimulai dari tahun 2015-2018, nilai rata-rata siswa perkelas masih dibawah KKM yang ditetapkan sekolah yaitu 71 , dengan nilai rata-rata keseluruhan adalah 65,33 . Selain itu, di sekolah tersebut masih banyak siswa yang sulit untuk memahami materi yang diberikan oleh guru. Sementara banyak siswa yang mampu dalam pembelajaran namun masih kurang memahami apa yang disampaikan. Oleh karena itu di sekolah tersebut siswa-siswanya masih sangat tertinggal dalam pembelajaran, yang berakibat pada rendahnya hasil belajar matematika siswa.

Mullis menyatakan bahwa "sebagian besar pembelajaran matematika belum berfokus pada pengembangan penalaran matematika siswa, secara umum pembelajaran matematika masih tradisional". Akibatnya, matematika hingga saat ini masih dipandang sebagai salah satu pembelajaran yang sangat menakutkan dan membosankan, hanya orang-orang tertentu saja yang ingin mempelajarinya (Sugianti, 2009:2). Oleh karena itu dibutuhkan model pembelajaran yang dapat menarik minat siswa, salah satunya adalah model discovery learning. Metode penemuan adalah terjemahan dari Discovery. Menurut Aqib (2013:118) menyatakan bahwa Discovery adalah proses mental dimana siswa mampu mengasimilasikan sesuatu konsep atau prinsip. Yang dimaksud proses mental tersebut yaitu mengamati, mencerna, mengerti, menggolong-golongkan, membuat dugaan, menjelaskan, mengukur, memuat kesimpulan dan sebagainya. Dalam teknik ini siswa dibiarkan menemukan sendiri, guru hanya membimbing. Dalam discovery learning siswa didorong untuk belajar sendiri secara mandiri. Siswa belajar melalui keterlibatan aktif dengan konsep-konsep dan prinsip-prinsip dalam memecahkan masalah, dan guru mendorong siswa untuk mendapatkan pengalaman dengan melakukan kegiatan yang memungkinkan siswa menemukan prinsip-prinsip untuk diri mereka sendiri, bukan memberi tahu tetapi memberikan kesempatan atau dengan berdialog agar siswa menemukan sendiri. Sehingga dengan penerapan model pembelajaran discovery learning dapat meningkatkan hasil belajar siswa dan aktivitas belajar siswa (cintia, 2018; Putri, 2017; Mubarok, 2014).

Selain itu, pembelajaran matematika dengan pendekatan konstruktivisme, siswa mengkonstruksi sendiri pengetahuannya yang dimiliki baik secara individu maupun bersama teman (kelompok), dalam usaha mengembangkan kemampuan penalarannya. Dalam pembelajaran konstruktivisme, siswa mengkonstruksi pengetahuannya melalui diskusi kelompok sehingga mampu meningkatkan kemampuan penalaran dan prestasi matematika siswa. Hal ini bertentangan dengan pembelajaran konvensional bahwa guru hanya memindahkan pengetahuannya kepada siswa atau siswa hanya menerim pengetahuan yang sudah jadi dari gurunya, sehingga pembelajaran seperti ini kurang mampu meningkatkan kemampuan penalaran siswa yang diharapkan akan berdampak pada hasil belajar siswa.

Berdasarkan latar belakang di atas maka tujuan dari penelitian ini adalah untuk mengetahui perbedaan peningkatan hasil belajar matematika siswa yang diajar dengan menggunakan model pembelajaran discovery learning dengan pendekatan kontruktivisme dan siswa yang diajar dengan model pembelajaran konvensional. 


\section{METODE}

Jenis penelitian ini adalah penelitian Quasi eksperimen yang melibatkan dua kelas yaitu kelas eksperimen dan kelas kontrol. Kelas eksperimen diberi perlakuan dengan menggunakan model pembelajaran discovery learning dengan pendekatan kontruktivisme dan pada kelas kontrol menggunakan pembelajaran konvensional sebagaimana biasanya.

\subsection{Populasi Penelitian}

Populasi adalah wilayah generalisasi yang terdiri atas objek atau subjek yang mempunyai kualitas dan karakteristik tertentu yang ditetapkan oleh peneliti untuk dipelajari dan kemudian ditarik kesimpulannya (Sugiyono, 2016 :61). Populasi pada penelitian ini adalah seluruh siswa kelas VIII SMP Negeri 2 Loea, semester genap pada tahun ajaran 2017/2018. Gambaran populasi dalam penelitian ini diperlihatkan pada Tabel 1.

\begin{tabular}{|c|c|c|}
\hline No. & Kelas & Jumlah siswa \\
\hline 1 & VII A & 21 \\
\hline 2 & VII B & 17 \\
\hline \multicolumn{2}{|c|}{ Jumlah } & 38 \\
\hline
\end{tabular}

\subsection{Sampel Penelitian}

Sampel adalah bagian dari jumlah dan karakteristik yang dimiliki oleh populasi. Apa yang dipelajari dari sampel itu, kesimpulannya akan dapat diberlakukan untuk populasi. Untuk itu sampel yang diambil dari populasi harus betul-betul representatif (Sugiyono, 2016: 62). Karena populasi dalam penelitian ini hanya dua kelas dan kebutuhan penelitian juga dua kelas, maka sampel dalam penelitian ini menggunakan sampel jenuh yaitu semua populasi menjadi sampel. Selanjutnya Kelas VIIA dipilih sebagai kelas Eksperimen dan kelas VIIB sebagai kelas kontrol.

\subsection{Desain Penelitian}

Desain penelitian ini adalah non equivalen control group design dimana pada awal dan akhir pembelajaran kedua kelas diberi tes. Desain penelitian disajikan pada Gambar 2.

\begin{tabular}{|llll|}
\hline$K E$ & $O_{1}$ & $X$ & $O_{2}$ \\
$K K$ & $O_{3}$ & - & $O_{4}$ \\
\hline
\end{tabular}

\subsection{Metode Pengumpulan Data}

1. Tes

Tes diberikan kepada siswa pada akhir perlakuan. Digunakan untuk mengetahui kemampuan pemecahan masalah matematika siswa. Instrumen yang digunakan berupa soal tes dimana soal yang digunakan adalah soal-soal matematika yang sebelumnya telah diuji valid dan reliabel serta diperhatikan tingkat kesukaran dan daya pembedanya. 


\section{Observasi}

Observasi digunakan untuk memperoleh informasi terkait dengan aktivitas siswa selama proses pembelajaran berlangsung dan aktivitas guru dalam mengelola kelas. Instrumen yang digunakan berupa lembar observasi. lembar observasi digunakan untuk mengetahui bagaimana aktivitas siswa selama pembelajaran berlangsung dan aktivitas guru dalam mengelola kelas baik pada kelas eksperimen maupun kelas kontrol.

\subsection{Metode Analisis Data}

Untuk mendeskripsikan atau menggambarkan data penelitian dihitung mean, median, modus, rang, varians dan standar deviasi. Sedangkan untuk melihat peningkatan hasil belajar masing-masing kelas, maka dihitung $N$-Gain dari kedua kelas dengan rumus (1).

$$
g=\frac{S_{\text {postest }}-S_{\text {pretest }}}{S_{\text {maksimum }}-S_{\text {pretest }}}
$$

Selanjutnya nilai gain yang diperoleh diklasifikasikan sesuai klasifikasi pada Tabel 2.

\begin{tabular}{cl}
\multicolumn{2}{c}{ Tabel 2. Klasifikasi N - Gain } \\
\hline N-Gain & \multicolumn{1}{c}{ Klasifikasi } \\
\hline $\mathrm{g} \geq 0,7$ & Tinggi \\
$0,3 \leq \mathrm{g}<0,7$ & Sedang \\
$0<\mathrm{g}<0,3$ & Rendah \\
$\mathrm{g}=0$ & Tidak meningkat \\
$\mathrm{g}<0$ & Menurun \\
\hline
\end{tabular}

Untuk melihat perbedaan peningkatan hasil belajar pada kelas kontrol dan kelas eksperimen digunakan uji t dengan rumus

$$
t=\frac{\left(\bar{X}_{1}-\bar{X}_{2}\right)}{\sqrt{\frac{\left(n_{1}-1\right) s_{1}^{2}+\left(n_{2}-1\right) s_{2}^{2}}{n_{1}+n_{2}-2}\left(\frac{1}{n_{1}}+\frac{1}{n_{2}}\right)}}
$$

yang mana sebelumnya data diuji normal menggunakan uji normalitas kolmogorov-smirnov dan dan homogenitas menggunakan uji F.

Adapun hipotesis yang digunakandalam penelitian ini adalah sebagai berikut.

$\mathrm{H}_{0}$ : Tidak terdapat perbedaan peningkatan hasil belajar antara siswa yang belajar menggunakan model pembelajaran discovery learning dengan pendekatan kontruktivisme dengan siswa yang belajar menggunakan model pembelajaran konvensional.

$\mathrm{H}_{1}$ : Terdapat perbedaan peningkatan hasil belajar antara siswa yang belajar menggunakan model pembelajaran discovery learning dengan pendekatan kontruktivisme dengan siswa yang belajar menggunakan model pembelajaran konvensional. 


\section{HASIL PENELITIAN}

Penelitian ini dilaksanakan pada Tanggal 28 April 2018 sampai 11 Mei 2018 di kelas VII SMP Negeri 2 Loea Semester Genap Tahun Ajaran 2017/2018. Penelitian ini dilakukan sebanyak 6 pertemuan yang terdiri dari pretest pada pertemuan 1, pemberian perlakuan pada pertemuan 2 hingga pertemuan 5, dan posttest pada pertemuan 6. Pretest diberikan pada awal pertemuan, sedangkan posttest diberikan pada akhir pertemuan. Adapun materi yang diajarkan di kedua kelas pada penelitian ini adalah kubus dan balok.

\subsection{Data Pretest Hasil Belajar Matematika Siswa}

Pretest diberikan sebelum siswa mendapatkan perlakuan berupa penerapan metode pembelajaran guided inquiry untuk kelas eksperimen dan pembelajaran konvensional untuk kelas kontrol. Pretest ini bertujuan untuk melihat gambaran kemampuan awal masing-masing kelas. Gambaran umum hasil pretest tersebut disajikan pada Tabel 3.

Tabel 3. Analisis Deskriptif Data Pretest

\begin{tabular}{ccc}
\hline Statistik Deskriptif & Kelas Eksperimen & Kelas Kontrol \\
\hline Banyak Data & 21 & 17 \\
Nilai Terendah & 40 & 30 \\
Nilai Tertinggi & 78 & 75 \\
Range & 38 & 45 \\
Rata-rata & 55,905 & 55,71 \\
Modus & 70 & - \\
Median & 60 & 60 \\
Varians & 194,99 & 160,10 \\
Standar Deviasi & 13,96 & 12,65 \\
\hline
\end{tabular}

\subsection{Data Posttest Hasil Belajar Matematika Siswa}

Data posttest menunjukkan hasil belajar matematika siswa pada materi kubus dan balok setelah dilakukannya proses pembelajaran. Gambaran umum hasil posttest tersebut disajikan pada Tabel 4.

Tabel 4. Analisis Deskriptif Data Posttest

\begin{tabular}{ccc}
\hline Statistik Deskriptif & Kelas Eksperimen & Kelas Kontrol \\
\hline Banyak Data & 21 & 17 \\
Nilai Terendah & 65 & 58 \\
Nilai Tertinggi & 87 & 82 \\
Range & 22 & 24 \\
Rata-rata & 77,95 & 74,18 \\
Modus & 80 & 75 \\
Median & 80 & 75 \\
Varians & 45,15 & 52,78 \\
Standar Deviasi & 6,72 & 7,26 \\
\hline
\end{tabular}




\subsection{Data Peningkatan Hasil Belajar Matematika Siswa}

Berdasarkan data pretest dan posttest yang telah diperoleh, selanjutnya dilakukan perhitungan nilai N-Gain. Perhitungan ini digunakan untuk mengetahui besar peningkatan hasil belajar siswa. Gambaran umum hasil perhitungan N-Gain disajikan pada tabel 5.

\begin{tabular}{ccc}
\multicolumn{3}{c}{ Tabel 5. Analisis Deskriptif Data N-Gain } \\
\hline Statistik Deskriptif & Kelas Eksperimen & Kelas Kontrol \\
\hline Banyak Data & 21 & 17 \\
Nilai Terendah & 0,33 & 0,22 \\
Nilai Tertinggi & 0,63 & 0,56 \\
Range & 0,3 & 0,34 \\
Rata-Rata & 0,49 & 0,41 \\
Modus & - & 0,375 \\
Median & 0,48 & 0,4 \\
Varians & 0,0058 & 0,0074 \\
Standar Deviasi & 0,0764 & 0,0861 \\
\hline
\end{tabular}

\subsection{Analisis Lembar Observasi Guru}

Lembar observasi guru digunakan untuk melihat, apakah guru dapat melaksanakan proses pembelajaran sesuai dengan sintaks yang ada dalam model pembelajaran discovery learning dengan pendekatan kontruktivisme dan model Pembelajaran Konvensional. Hasil lembar observasi tersebut disajikan pada diagram pada Gambar 3.

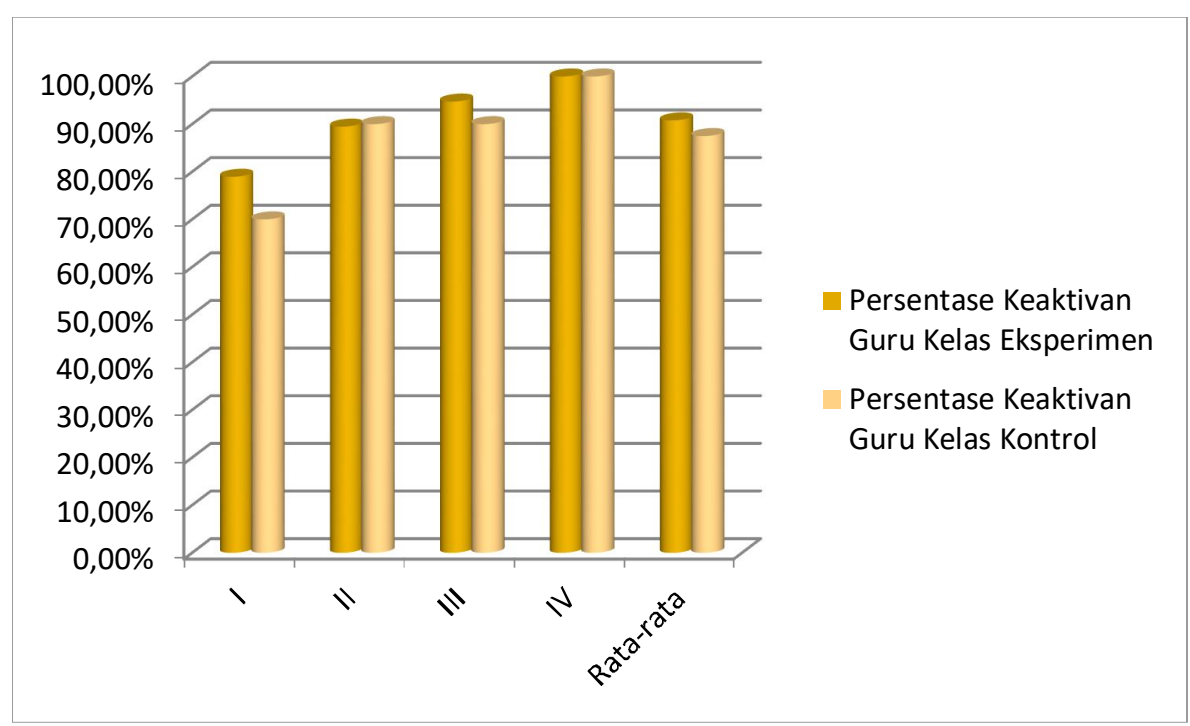

Gambar 3. Hasil Analisi Lembar Observasi Guru

Dari hasil analisis lembar observasi guru pada diagram 3, terlihat bahwa peresentase nilai rata-rata aktivitas guru dalam proses pembelajaran menggunakan model pembelajaran discovery learning dengan pendekatan kontruktivisme adalah $90,79 \%$ berada pada kategori sangat aktif dan rata-rata keaktivan guru pada kelas dengan model pembelajaran konvensional $87,5 \%$ berada pada kategori sangat aktif. 


\subsection{Analisis Lembar Observasi Aktivitas Siswa}

Lembar penilaian aktivitas siswa digunakan untuk melihat keaktivan siswa selama proses pembelajaran berlangsung. Hasil lembar observasi tersebut disajikan pada Gambar 4.

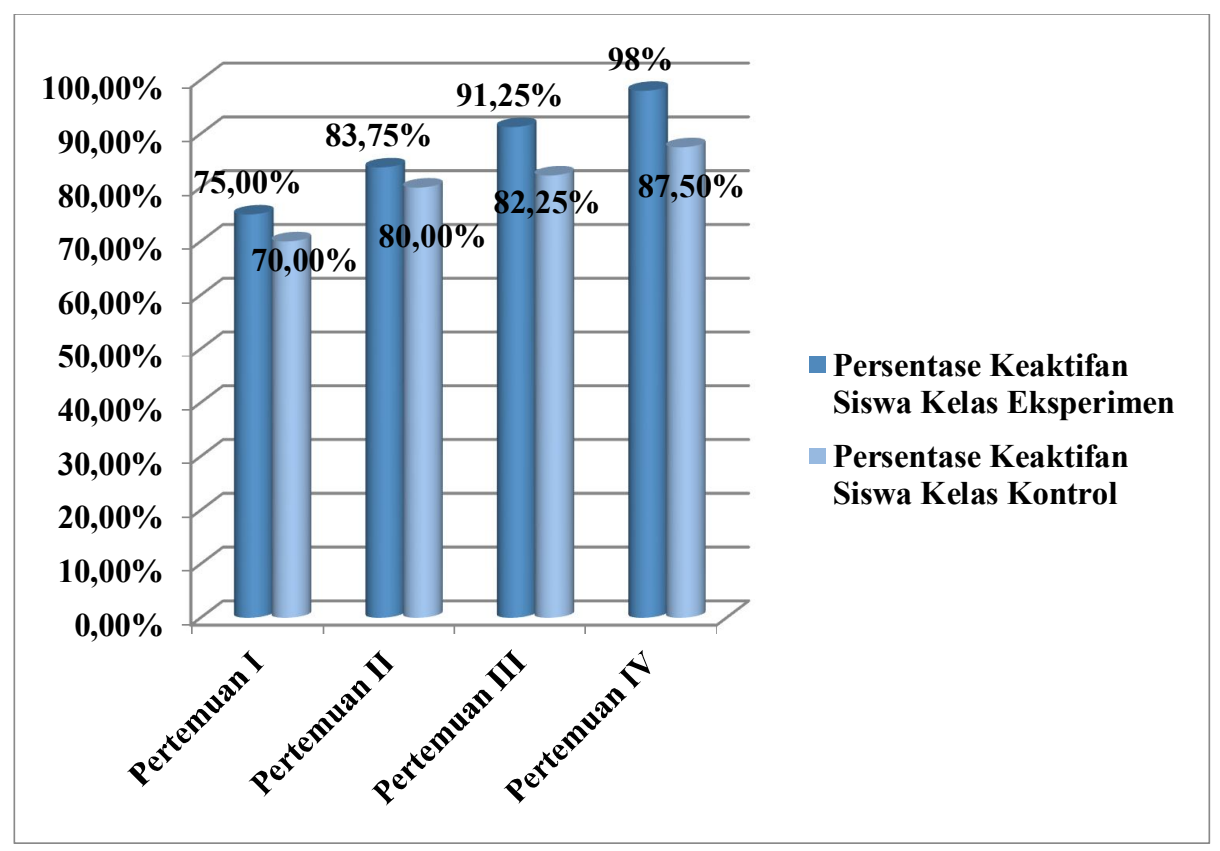

Diagram 4. Hasil Analisi Lembar Observasi Siswa

Dari hasil analisis pada Gambar 4, terlihat bahwa peresentase nilai rata-rata aktivitas siswa dalam proses pembelajaran menggunakan model pembelajaran discovery learning dengan pendekatan kontruktivisme sebesar $98 \%$ berada pada kategori sangat aktif dan rata-rata aktivitas siswa dalam proses pembelajaran menggunakan metode konvensional sebesar $87,5 \%$ berada pada kategori sangat aktif.

\subsection{Analisis Inferensial}

Untuk menjawab tujuan peneletian maka dilakukan analisis inferensial pada data peningkatan hasil belajar siswa (N-Gain). Dimulai dengan uji normalitas data pada kelas eksperimen dan kelas kontrol. Berdasarkan uji yang telah dilakukan pada taraf signifikansi $\alpha=5 \%$ diperoleh hasil pada Tabel 6 .

Tabel 6. Uji Normalitas Data

\begin{tabular}{lccc}
\hline Uji Normalitas & $D_{\text {hit }}$ & $D_{\text {tab }}$ & Kesimpulan \\
\hline kelas eksperimen & 0,133 & 0,278 & Normal \\
kelas kontrol & 0,115 & 0,318 & Normal \\
\hline
\end{tabular}

Dari Tabel 6, diperoleh bahwa data kedua kelompok berdistribusi normal, selajutnya dilakukan uji homogenitas untuk melihat kesamaan varians kedua kelompok dan diperoleh hasil $F_{\text {hitung }}=1,28$ dan $F_{\text {tabel }}=2,18$. Karena $F_{\text {hitung }}<F_{\text {tabel }}(1,28<2,18)$ maka dapat disimpulkan data memiliki varians yang sama atau homogen. 
Berdasarkan uji prasyarat yang dilakukan, diperoleh hasil data berdistribusi normal dan homogen maka pengujian hipotesis menggunakan t-test Polled Varian. Berdasarkan hasil analisis uji hipotesis dengan menggunakan uji t diperoleh $t=3,14$ dan $t_{\text {tabel }}(\alpha=0,05 ; d k=36)$ $=2,03$. Karena $t_{\text {hitung }}>t_{\text {tabel }}(3,14>2,03)$ maka $\mathrm{H}_{0}$ ditolak dengan kata lain terdapat perbedaan rata-rata peningkatan hasil belajar matematika antara kelas kontrol dan kelas eksperimen.

\section{PEMBAHASAN}

\subsection{Hasil Belajar Matematika Siswa}

Berdasarkan hasil penelitian, ditemukan bahwa secara deskriptif siswa yang diajar menggunakan model pembelajaran Discovery Learning dengan pendekatan kontruktivisme dan siswa yang diajar dengan menggunakan model pembelajaran konvensional pada awalnya memiliki rata-rata nilai yang hamper sama yaitu 55,905 dan 55,71 begitupula untuk nilai terendah, nilai tertinggi, modus dan median. Sedangkan rata-rata hasil posttes kelas eksperimen $(77,95)$ lebih tinggi dibandingkan kelas kontrol $(74,18)$ begitupula dengan nilai terendah, nilai tertinggi, modus dan median kelas eksperimen lebih tinggi dibanding kelas kontrol. Selanjutnya, bila diperhatikan selisih dari nilai pretest dan posttest kelas eksperimen juga memiliki rata-rata selisih nilai $(22,05)$ yang lebih tinggi dibandingkan dengan kelas kontrol $(18,47)$.Hal ini menunjukkan bahwa secara deskriptif penerapan model pembelajaran Discovery Learning dengan pendekatan kontruktivisme lebih baik dibandingkan dengan penerapan model pembelajaran konvesnsional pada materi bangun datar segi empat.

\subsection{Kemampuan Guru Mengelola Pembelajaran}

Kemampuan guru dalam mengelola pembelajaran baik pada kelas eksperimen maupun pada kelas kontrol secara umum terlaksana dengan baik, hal ini sesuai dengan pengamatan observer selama 4 (tiga) kali pertemuan secara berturut-turut. Hal ini dapat dilihat melalui nilai rata-rata persentase keaktifan guru dalam proses pembelajaran pada kelas eksperimen sebesar $90,79 \%$, sedangkan nilai rata-rata persentase keaktifan guru dalam proses pembelajaran pada kelas kontrol sebesar $87,50 \%$. Hal tersebut dikarenakan guru yang mengajar di kedua kelas tersebut adalah guru yang sama dan pada saat mengajar di kelas eksperimen maupun di kelas kontrol telah menciptakan suasana yang kondusif, nyaman, dan bersahabat. Sehingga dapat mendorong siswa untuk lebih termotivasi dalam belajar dan aktif dalam proses pembelajaran.

Nilai rata-rata persentase keaktifan guru dalam proses pembelajaran tersebut menunjukkan bahwa aktivitas guru dalam proses pembelajaran baik pada kelas eksperimen maupun kelas kontrol termasuk dalam kategori sangat aktif.

\subsection{Aktivitas Siswa dalam Mengikuti Proses Pembelajaran}

Hasil pengamatan observer terhadap aktivitas siswa dalam proses pembelajaran baik pada kelas eksperimen maupun pada kelas kontrol menunjukkan bahwa semua aspek yang diamati secara umum terlaksana dengan baik selama 4 (tiga) kali pertemuan. Hal ini dapat dilihat melalui nilai rata-rata persentase aktivitas siswa dalam proses pembelajaran pada kelas eksperimen sebesar $86,68 \%$, sedangkan nilai rata-rata persentase aktivitas siswa pada kelas kontrol sebesar $79,94 \%$. Dari nilai rata-rata persentase aktivitas siswa dalam proses 
pembelajaran tersebut tampak bahwa siswa pada kelas eksperimen atau kelas yang diajar dengan menggunakan model pembelajaran Discovery Learning dengan pendekatan kontruktivisme lebih aktif dibandingkan dengan siswa yang diajar dengan menggunakan model pembelajaran konvensional. Hasil ini semakin mendukung teori yang mengatakan bahwa salah satu keuntungan model pembelajaran Discovery Learning dengan pendekatan kontruktivisme adalah dapat meningkatkan keaktivan siswa dalam belajar.

\subsection{Pengaruh Pembelajaran}

Berdasarkan hasil penelitian dan analisis deskriptif yang telah diuraikan dapat disimpulkan bahwa pencapaian keefektifan pembelajaran baik pada model pembelajaran Discovery Learning dengan pendekatan kontruktivisme maupun model pembelajaran konvensional berada pada kategori baik untuk diterapkan pada materi pembelajaran Bangun Segi Empat siswa kelas VII SMP Negeri 2 Loea. Analisis lebih lanjut dengan membandingkan nilai rata-rata hasil belajar matematika siswa yaitu melalui hasil analisis inferensial, diperoleh bahwa hasil belajar siswa yang diajar dengan model pembelajaran Discovery Learning dengan pendekatan kontruktivisme lebih tinggi dibanding hasil belajar matematika siswa yang diajar dengan menggunakan model pembelajaran konvensional. Dengan demikian, penerapan model pembelajaran Discovery Learning dengan pendekatan kontruktivisme terbukti berpengaruh terhadap peningkatkan hasil belajar matematika siswa.

\section{SIMPULAN}

Dari hasil penelitian menggunakan uji hipotesis dan analisis statistik deskriptif menunjukkan bahwa terdapat perbedaan peningkatan hasil belajar matematika siswa yang menggunakan model pembelajaran Discovery Learning dengan pendekatan kontruktivisme dan pembelajaran konvensional. Model pembelajaran Discovery Learning dengan pendekatan kontruktivisme dapat meningkatkan kemampuan belajar siswa sehingga terdapat perbedaan yang cukup signifikan antara kelompok siswa yang belajar menggunakan model pembelajaran Discovery Learning dengan pendekatan kontruktivisme dan kelompok siswa yang belajar dengan pembelajaran konvensional. Selanjutnya, berdasarkan hasil penelitian ini, dapat disampaikan beberapa saran terkait dengan penelitian selanjutnya tentang model pembelajaran Discovery Learning dengan pendekatan kontruktivisme bahwa perlu diteliti pula mengenai faktor-faktor yang mempengaruhi tingkat keberhasilan dari model pembelajaran Discovery Learning dengan pendekatan kontruktivisme sehingga dapat menjadi bahan pembelajaran bagi para guru dalam menerapkan model pembelajaran Discovery Learning dengan pendekatan kontruktivisme.

\section{DAFTAR PUSTAKA}

Aqib, Zainal. 2013. Model-model, Media, dan Strategi Pembelajaran Kontekstual (inovatif). Bandung: Yrama Widdya.

Asra, Sumiati. 2007. Metode Pembelajaran. Bandung: CV. Wacana Prima. 
Cintia, Nitchen Irma dkk. 2018. penerapan model pembelajaran discovery learning untuk meningkatkan kemampuan berpikir kreatif dan hasil belajar siswa. Jurnal perspektif ilmu pendidikan, 31(1). 69-77.

Dimyati \& Mudjiono. 2007. Belajar dan Pembelajaran. Jakarta: Rineka Cipta.

Hendriana dan Soemarmo, 2014. Penilaian Pembelajaran Matematika. Bandung: Refika Aditama.

Hosnan, M. 2014. Pendekatan Saintifik dan Kontekstual dalam Pembelajaran abad 21. Bogor: Ghalia Indonesia.

Kadir. 2015. Tatistik Terapan Konsep, Contoh dan Analisi Data dengan Program SPSS/Lsrel dalam Penelitian. Jakarta: Raja Grafindo Persada.

Mubarok, Chusni \& Sulistyo Edy. 2014 Penerapan Model Pembelajaran Discovery Learning Terhadap Hasil Belajar Siswa Kelas X Tav Pada Standar Kompetensi Melakukan Instalasi Sound System di SMK Negeri 2 Surabaya. Jurnal Pendidikan Tekhnik Elektro. 3(1). 215-221.

Purwoto. 2003. Strategi Belajar Mengajar. Surakarta: UNS Press.

Putri, Ihdi Shabrona, dkk. 2017. Pengaruh Model Pembelajaran Discovery Learning Terhadap Hasil Belajar Siswa Dan Aktivitas Siswa. Jurnal Pendidikan Fisika. 6(2). 91-94.

Sudjana, Nana. 2008. Penilaian Hasil Belajar Mengajar. Bandung: Tarsito.

Siregar, Sofyan. 2015. Statistik Parametrik Untuk Penelitian Kuantitatif. Bumi Aksara: Jakarta.

Siswanto. 2017. Penilaian dan Pengukuran Sikap dan Hasil Belajar Peserta Didik. Klaten: Boss Script.

Sugiyono, 2014. Metode Penelitian Kuantitatif, Kualitatif dan R\&D. Bandung: Alfabeta.

Sugiyono, 2016. Satistika Untuk Penelitian. Bandung: Alfabeta.

Sundayana, R. 2014. Statistika Penelitian Pendidikan. Bandung: Alfabeta.

Walpole. E, Ronald. 2012. Probability \& Statistics for Engineers \& Scientists. United Statea: Pearson. 